\title{
Communication Points and Tools in the Air Transportation Operation Service Process: Ataturk Airport Implementation*
}

\author{
Savaş Selahattin Ateş, Celal Hakan Kağnıcıoğlu \\ Anadolu University, Eskisehir, Turkey
}

\begin{abstract}
Air transportation service is given by the complementary services of private companies like airline, airport, airport ground handling companies, and public institutions like customs, security, and border health administration. The companies in the process must communicate and interact each other and themselves fast and correct in order to present the planned air services. In this study, the tools and the usage places of these tools in the process of air transportation companies' operations are examined for Atatürk airport which is selected as the largest airport in Turkey. In the first part of this study, a literature review is given about the airline operation process used for flight planning, monitoring, and ground operation processes in the air transportation companies. In the second part, communication tools are listed by content analysis. In the last part of the study, the lists are evaluated by the operational personnel of the air transportation companies in Atatürk Airport with semi-structured interviews. Finally, a network diagram showing the communication points and communication tools in air transportation operation service process for Atatürk Airport is developed.
\end{abstract}

Keywords: air transportation operation service, communication points, communication tools, Atatürk airport

\section{Introduction}

Air transportation is a service to get advantage of place and time for transportation of passengers, baggage, mails, and cargos between two points with an aircraft. Airline passengers and cargo companies take the transportation services from the other air service companies. However, the services supplied by the airlines are the integration of more than one companies' services that are complementary to each other. Airline companies work with other companies such as airports, airport ground handlings, security, customs, and etc. to perform the flight operations. The shareholders use various tools for the planning of flight operation process. These tools serve as a bridge connecting the participating companies to each other during the service process.

The most important shareholders in the flight operation process are airline, airport, and ground handling companies. The presentation of service safely, economically and uninterruptedly depends on working with the

\footnotetext{
* Project Supported: This study was supported by Anadolu University Scientific Research Projects Commission under the grant of No. $1005 \mathrm{~F} 105$.

Savaş Selahattin Ateş, Ph.D., assistant professor, Anadolu University, Faculty of Aeronautics and Astronautic Department of Aviation Management.

Celal Hakan Kağnıcıŏglu, Ph.D., associate professor, Anadolu University, Faculty of Economics and Administrative Sciences, Department of Business Administration, Eskişehir, Turkey.

Correspondence concerning this article should be addressed to Celal Hakan Kağnıcıŏlu, Anadolu University, İİBF Yunus Emre Kampusu, 26470, Eskisehir, Turkey. E-mail: chkagnic@anadolu.edu.tr.
} 
standards set by ICAO (International Civil Aviation Organization). These standards determine the structure and content of the communication points and tools in the operation. Therefore, airline services can be given on time with required safety and reliability standards (Kazda \& Caves, 2000).

The airline companies manage the operation process under the control of A-OCC (Airline Operation Control Center) (Castro \& Lewis, 2011). There are tactical units under A-OCC. These units are responsible for the management of daily flight operations. The A-OCC is responsible for the implementation of the planned schedules and for updating the operation schedules in the operation process (Kazda \& Caves, 2000). The success of the operation depends on the coordinated working of A-OCC's departments with other companies. Departments of A-OCC can be listed as follows (Kazda \& Caves, 2000; Kohl, A. Larsen, J. Lasren, Ross, \& Tiourine, 2004) :

- operation management group;

- flight dispatch department;

- crew planning department;

- station operation control department;

- maintenance operation control department;

- support group.

The sub-groups of A-OCC have communication interactively with the airport in the process of operation. Airports are the most important infrastructure providers of the flight operation process. Capacity planning is under the responsibility of slot planning and slot coordination departments in airports. Air Traffic Control Department is responsible for transit overflights, approaches of aircrafts, and movement area operations (operation of an aircraft in the Runway, Apron, and Taxiway). In addition to these departments, apron management service department is responsible for the services performed in the apron. Slot planning, ATC, and Apron Management Departments have plans according to the operation decisions of airline companies. These departments manage the operations like flight information systems, security services, allocation systems of check-in desks and gates, announcement systems, baggage carousels, ramp area, and etc. in the movement area and terminal building according to the plans of A-OCC (Directorate General of Civil Aviation, 2008). For this reason, the information coming from A-OCC plays an important role in the management of these operations.

Another shareholder that always has communication with the departments of A-OCC is airport ground handling companies. Airport ground handling is defined as a service that is given to aircraft, passenger, baggage, and cargo during the period of landing to take off an aircraft (Directorate General of Civil Aviation, 1996). Airport ground handling companies are responsible for most of the services supplied directly to aircrafts, crews, passengers, baggage, mails, and cargos. These service operations are managed by G-OCC (Ground Handling Operation Control Center) with departments of resource planning, ramp, operation, passenger service, cargo, and support group (Figure 1). Supplied services by these departments are described in detail in the SGHA (Standard Ground Handling Agreement).

Other companies which are contributing to the flight operation process are listed as cargo agents, aircraft maintenance companies, corporations of aviation security, customs, and meteorology, civil aviation authorities, and other aviation companies. All of these companies (shareholders) work together directly or indirectly for the planning and management of the flights operation process (Clarke, Lettovsk, \& Smith, 2000). 


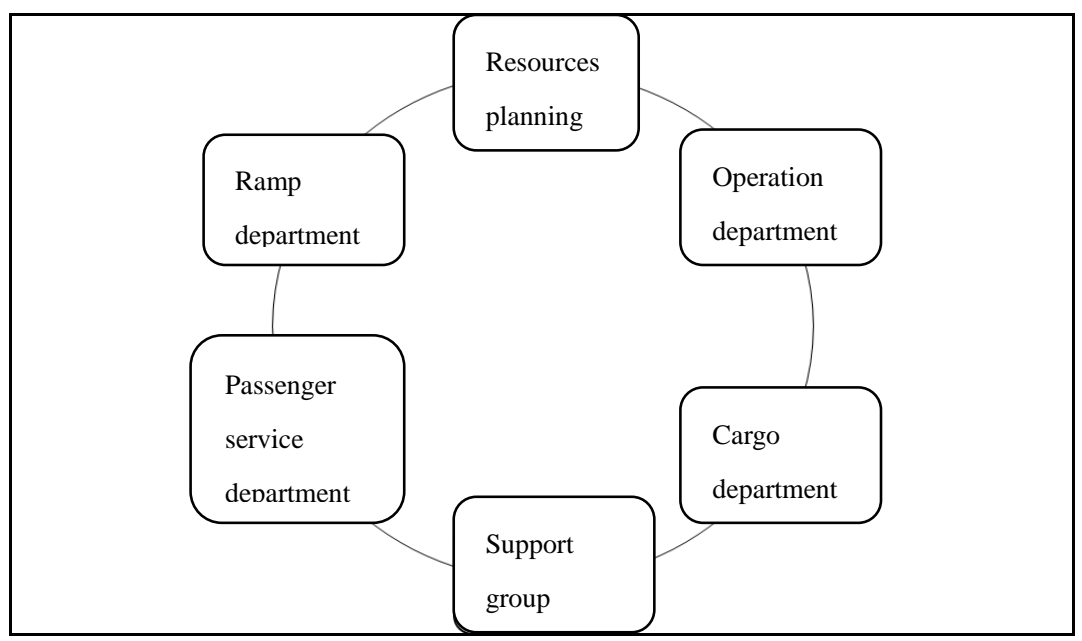

Figure 1. Ground handling operation control center.

The service process steps that are given by the shareholders can be summarized as follows:

- Departing passenger: The process is started with entrance to the airport for the departing passenger. Passengers and baggage are separated during the check-in step. After that, departing passenger passes through the security check. The passengers are subject to passport control, if the flight is an international one. After the boarding step, the passengers get on the plane (Curcio, Longo, Mirabelli, \& Pappoff, 2007; Ma, Kleinschmidt, Fookes, \& Yarlagadda, 2011).

- Departing baggage: Departing baggage, separated from the passenger after the check-in step, is subject to baggage screening. Then, loading process begins after the baggage is sorted according to the flights (Jim \& Chang, 1998);

- Departing cargo: The process started with acceptance of the departing cargo. Documentation and security control steps are completed after the cargo is unloaded from the land vehicles. Re-packaging (pelleting) operation is performed in the next step. Finally, departing cargo is brought to the aircraft and then loaded on the aircraft (Khan, 2000);

- Departing crew: Departing crew passes through the security and passport control process. After that, they get on the aircraft;

- Arriving/Departing aircraft: After arriving aircraft landing in the runway, it goes to the park position through the taxiways. Then, GPU (Ground Power Unit) is connected to the aircraft, chocks and safety cones are positioned, and flashing lights are switched off. The passenger bridges and steps are connected to the aircraft and gates are opened. After that, unboarding of the cargo, baggage, mail, and passengers is performed. After the crew takes over the aircraft, the information is entered to the computers by the pilots. Furthermore, pilots brief the weather conditions of arrival airports and calculate the performance of the flight legs. Fuelling, cleaning, watering, air conditioning, and other necessity services are delivered to the aircraft simultaneously. Aircraft gates are closed, after is the completion of technical controls, weight balance calculations, loading of cargo, baggage, and passengers. The GPU is disconnected and chocks and safety cones are displaced. Flashing lights are turned on, push-back is started, and then de/anti-icing is finished if it is necessary. After the air traffic control clearance, aircraft can use taxiway and go to the holding position. And then, aircraft takes off (Norin, 2008);

- Arriving passenger: After the unloading of arriving passengers, they are carried to terminal building and wait for their baggage. Arriving passengers go out of the terminal, after they take baggage (Gatersleben \& Weij, 1999); 
- Arriving baggage: Arriving baggage is unloaded from the aircraft. Then it is loaded to the baggage belt of the carousels and meets with the owners (Jim \& Chang, 1998);

- Arriving cargo: The pallets are distributed, after the arriving cargo is unloaded from the aircraft. The cargo is passed through the document check and loaded into the land vehicles (Khan, 2000);

- Transit-transfer passenger: The transit-transfer passengers get out of the aircraft and are directed to the connected flight.

\section{Purpose and Method}

Air transportation sector employs over 56.6 million people in the world. The sector's contribution to the world GDP is about 2.2 billon dollar (Air Transport Action Group, 2013). The air transportation sector is very sensitive to the external risk factors, such as economic and political crises, fluctuation of fuel prices, and development of new technologies. It is not possible for the companies in this sector to manage the external risk factors directly originated from the outside of this sector. Therefore, the planning and managing of the flight operation service effectively are very important for the sustainability of companies which have low-cost flexibility.

The study is carried out to define the flight operation process, to expose the tools which are used for communication, and to determine the important process steps in which some verbal communications have to be done. Finally, a network diagram showing the communication points and tools in the flight operation service process for Atatürk Airport was developed.

Atatürk Airport, the biggest airport in Turkey, was selected for the implementation. The report notebooks of 34 Anadolu University Civil Aviation Management students completing their summer practice in the Atatürk Airport from 2006 to 2010 years, were used for the content analysis.

The communication tools and points which are used in the flight operation services were listed at the end of content analysis. These lists were verified by 10 operation personnel who have been working in the air transportation sector in Atatürk Airport. Semi-structured interview method was preferred during the verification stage.

The data of content analysis and semi-structured interviews were evaluated with the method of Miles and Huberman interpretative approaches (1994). This method allows researchers to explain human activity and social action. Interviews and observational data are recorded into written text for analysis. Framing data are used by coding or various sorting operations as tables and figures. This method provides a means for discovering the practical understanding of meanings and actions (Miles \& Huberman, 1994). In the first stage of study, the data which were collected from content analysis and semi-structured interviews were sorted as items. In the second stage, items were summarized by tables. In the third and final stage, the results were recovered from themes and relations in the tables. Then, a network diagram showing the communication points and tools was developed for Atatürk Airport.

\section{Results and Analysis}

Routinely used documents, tools, and verbal communication points in the flight operation service are demonstrated by the tables with results of semi-structured interviews and content analysis of the internships report books. Shareholders usually prefer documents set by international standards for communication by themselves and other companies. The documents routinely used in the flight operation management are listed in Table 1. These documents, which are filled by authorized personal, include information about the operations of the companies. These documents can be shared with other companies for giving information, if it is needed. 
Table 1

Documents Routinely Used in Flight Operation

\begin{tabular}{|c|c|c|c|}
\hline $\begin{array}{l}\text { Documents } \\
\text { Abbv. }\end{array}$ & Contents & Edited By & Distributed To \\
\hline ADCS & Arrival-departure checking and searching form & Handling Co. & Customs \\
\hline ADR & Aircraft damage report & Handling Co. & Airline Co. \\
\hline ASD & Agency security declaration form & Cargo Agnt. & Shareholders \\
\hline AWB & Airway bill & Cargo Agnt. & Shareholders \\
\hline $\mathrm{BL}$ & Baggage label & Handling Co. & Baggage \\
\hline BLCL & Bulk load check list & Operation Per. & RampPer. \\
\hline BP & Boarding Pass & Handling Co. & Passenger \\
\hline CCAF & Check-in counters assigned to the form & Terminal Co. & Handling Co. \\
\hline $\mathrm{CF}$ & Catering form & Catering Co. & Airline Co. \\
\hline $\mathrm{CCF}$ & Cabin cleaning form & Hanling Co. & Airline Co. \\
\hline $\mathrm{CDF}$ & Customs declaration form & Hanling Co. & Customs \\
\hline $\mathrm{CI}$ & Captain info & Hanling Co. & Pilots \\
\hline $\mathrm{CIS}$ & Cabin information sheet & Hanling Co & Cabin Crew \\
\hline $\mathrm{CL}$ & Cargo label & Cargo Agnt. & Cargo \\
\hline $\mathrm{CM}$ & Cargo manifest & Hanling Co. & Shareholders \\
\hline $\mathrm{COM}$ & Comail & Hanling Co. & Hanling Co. \\
\hline DPF & Deportee passenger form & Hanling Co. & Shareholders \\
\hline EBF & Excess baggage form & Handling Co. & Passenger \\
\hline $\mathrm{FE}$ & Flight envelope & Dispatch & Pilots \\
\hline FMF & Flight and maintenance form & Technic Per. & Shareholders \\
\hline FP & Flight plan & Airline Co. & Shareholders \\
\hline GENDEC & General Declaration & Crew & Customs \\
\hline HIR & Handling irregularity report & Hanling Co. & Airline Co. \\
\hline LI & Load info & Hanling Co. & Pilots \\
\hline LIR & Loading instruction report & Operation Per. & Ramp Per. \\
\hline LS & Load sheet & Hanling Co. & Pilots \\
\hline NOTAM & Notice to airmen & Authority & Shareholders \\
\hline PBF & Passenger bridge form & Terminal Co. & Airline Co. \\
\hline PIR & Property irregularity report & Hanling Co. & Passenger \\
\hline $\mathrm{PM}$ & Passenger manifest & Hanling Co. & Shareholders \\
\hline PRL & Passenger reservation list & Airline Co. & Hanling Co. \\
\hline $\mathrm{PT}$ & Passenger ticket & Airline Co. & Shareholders \\
\hline PS & Passenger service list & Airline Co. & Shareholders \\
\hline SCI & Special cargo information & Cargo Agnt. & Shareholders \\
\hline SE & Slot extension parking space availability form & Airport Co. & Airline Co. \\
\hline $\mathrm{SF}$ & Service form & Hanling Co. & Airline Co. \\
\hline TI & Trip info & Pilot & Fuel Co. \\
\hline TL & Technical logbook & Technic Per. & Shareholders \\
\hline ULDL & ULD load check list & Operation Per. & Cargo Per. \\
\hline $\mathrm{UM}$ & UM forms & Handling Co. & Passenger \\
\hline WDF & Weapon delivery form & Security Co. & Handling Co. \\
\hline WBF & Weight and balance form & Operation Per. & Ramp Per. \\
\hline WI & TAF-METAR-SPECI-Weather charts & Methorology & Shareholders \\
\hline
\end{tabular}


In addition to these documents, there are also some verbal communication points in the steps of the operation process. Verbal communication is preferred for fast communication. Start and finish times of process steps, data used for calculation, and permission for the start of operations are reported to the shareholders via verbal communications. That data are transmitted to G-OCC (Ground Handling Companies Operation Control Center) and then recorded. The shareholders have the right to access G-OCC to get the information when it is required. The verbal communication points in the operation process are demonstrated in

Table 2 .

Table 2

Verbal Communication Points Routinely Used in Flight Operation

\begin{tabular}{|c|c|c|c|}
\hline \begin{tabular}{|l} 
Verbal \\
Abbv.
\end{tabular} & Contents & By & To \\
\hline ACII & Aircraft inbound info & G-OCC & Departments \\
\hline ACIP & Aircraft in park position & Operation Per. & G-OCC \\
\hline AGCI & Aircraft gate close time info & Operation Per. & G-OCC \\
\hline AGOI & Aircraft gate open time info & Operation Per. & G-OCC \\
\hline ATCC & Air Traffic Clearance & Pilot & ATC \\
\hline BFTI & Boarding finish time info & Passenger S. Per. & G-OCC \\
\hline BOSC & Boarding start clearance & Passenger S. Per. & Cabin Crew \\
\hline BPCI & Boarded passenger count info & Passenger S. Per. & G-OCC \\
\hline BSTI & Boarding start time info & Passenger S. Per. & G-OCC \\
\hline CACC & Cabin cleaning clearance & Ramp Per. & Cabin Crew \\
\hline CHBI & Checked baggage count and weight info & Passenger S. Per. & G-OCC \\
\hline $\mathrm{CHCI}$ & Check-in close time info & Passenger S. Per. & G-OCC \\
\hline $\mathrm{CHOI}$ & Check-in open time info & Passenger S. Per. & G-OCC \\
\hline CHPI & Checked passenger count info & Passenger S. Per. & G-OCC \\
\hline LNDI & Aircraft landing time info & G-OCC & Departments \\
\hline PLTI & Passenger loading finish time info & Operation Per. & G-OCC \\
\hline PUTI & Passenger unloading finish time info & Operation Per. & G-OCC \\
\hline TOFI & Aircraft takeoff time info & Operation Per. & G-OCC \\
\hline
\end{tabular}

Not only documents but also verbal communication points are important for the management of the airline service process. After the documents are filled, they are send to the other related service process steps. In this way, information about the content of the document is clearly understood. Verbal and documental communication points are demonstrated in Figure 2 which is developed by the study of Operation-Based Network Diagram of Atatürk Airport Service Process Diagram (Ateş \& Kağnıcıŏglu, 2013). Abbreviations (Abbv.), used in the tables, are used in the figures, as well. Therefore, it is aimed to show the communication process for the steps of airline services process in Atatürk Airport completely.

Some tools are used for planning and monitoring of flight operations, getting the permission of some process, and announcement of the data to the shareholders in flight service process. Types and properties of tools which are used in the steps of the operation process are asked to operation personnel during the semi-structured interviews. 


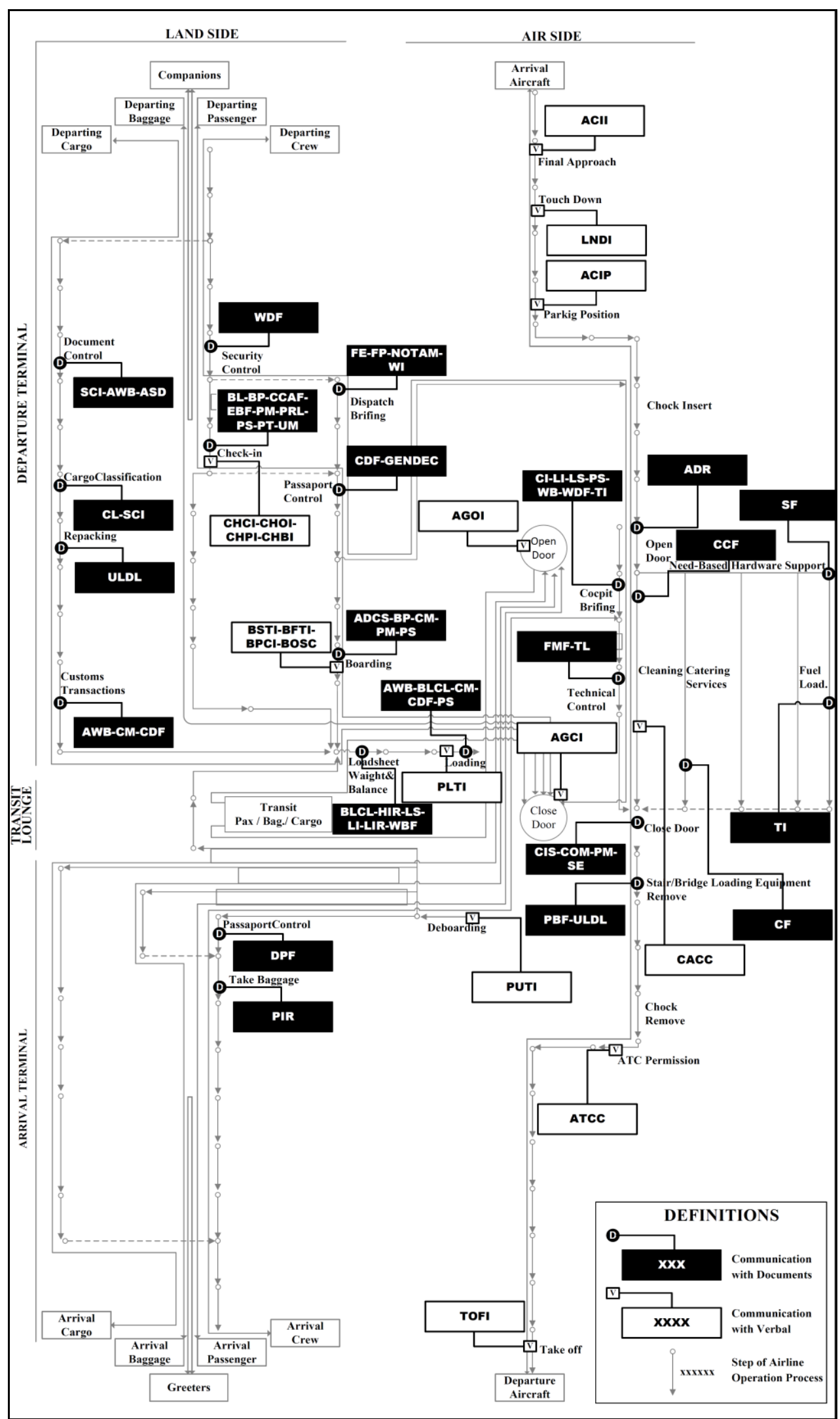

Figure 2. Communication points in the operation based network diagram of Ataturk Airport service process. 
The most widely used tools are transceiver, telephone, and SITA (Société Internationale de Télécommunications Aéronautiques) as it is shown in Table 3. The transceiver is a tool that is portable and has channel options and low cost. It has a limited range and can serve only one user at a time in a channel. These are some important limitations of a transceiver. SITA is a tool that has been used since 1949 by the air transportation companies for a network of communications that allows sharing of operation information (SITA, 2013). Besides, SITA has been offering some other solutions like operation planning tools and decision support systems for airports, airlines, terminals, and other shareholders for the last 20 years. Telephone is another tool which is preferred by shareholders for the communication. Moreover, the tools, working with the internet infrastructure, are also used in the management of operations. The most important reason of using these tools is the speed and low cost of these tools.

Table 3

Tools Used For the Flight Operation Management

\begin{tabular}{|l|l|l|}
\hline Company Type & Position & Tools \\
\hline \multirow{4}{*}{ Airline Co. } & Station Control \& Coordination Manager & OIS-ACARS-FWZ-Transceiver \\
\cline { 2 - 3 } & Flight Operation Manager & NETLINE-CFMU-Telephone-SITA-Internet \\
\hline \multirow{5}{*}{ Ground Handling Co. } & Operation Manager & Transceiver-Telephone-SITA-OIS \\
\cline { 2 - 3 } & Passenger Service Manager & Transceiver-Telephone-SITA-SAP-OIS \\
\cline { 2 - 3 } Terminal\&Airport Co. & Opanp Manager & Transceiver-Telephone-SITA \\
\cline { 2 - 3 } & Operation Manager & Telephone-Transceiver-Internet-SITA \\
\cline { 2 - 3 } & Operation \& Coordination Manager & OIS -SITA-ACARS-Telephone-Transceiver \\
\cline { 2 - 3 } & Senior Manager Assistant & Transceiver-Telephone-OIS \\
\cline { 2 - 3 } & Flight Man. \& Planning Chief & Transceiver-Telephone-OIS \\
\hline
\end{tabular}

Some of the shareholders are working with the OIS (Operation Information System) that are developed by themselves. Furthermore, a limited number of the OIS's as FWZ (Sabre f:wz), NETLINE (Lufthansa IT Systems), and etc. have become the commercial products that are used by the other companies in the management of flight operation process. In addition, the common ERP programs (Enterprise Resource Planning) as SAP can also be adopted by the companies. Additionally, the other systems as ACARS (Aircraft Communications Addressing and Reporting System) integrated to aircrafts can be used. Finally, flight information screens and announcement systems are used as the basic systems for the communication of the passengers by the shareholders. All these tools that are used in the steps of the flight operation process are aimed to facilitate the planning and monitoring of the steps of the operation process.

\section{Conclusions}

The documents, verbal communication points and tools, which are routinely used for the management of airline service process in Atatürk Airport, are listed within this study. Moreover, communication points are demonstrated on the operation-based network diagram of service process which is developed specially for Atatürk Airport. It is understood that verbal communication used for the operation process is not adequate for transmission of complex data. Recording and accessing of operational data after the date of operation are also important. Because of that, standard documents must be used in the steps of operation process. Well-prepared documents can accurately transfer a great deal of information in just a few seconds to operation personnel. In 
spite of the growing usage of the routine documentation transmission, face to face and voice contacted communication are still best ways to communicate the problems in operation process.

At the end of this study, one of the important key factors of the success of the operation process is to prevent the repeated activities like recording and calculation of the same data by different departments in the communication and documentation. Repeated recording of the same data and calculation of the same statistics in different ways cause the waste of time for the operation personnel.

Fast and correct communication is determined as an important key factor of the success of the planning, monitoring, and managing of operation process. In order to increase the productivity and effectiveness of the activities in the process, communication must be strengthened. One of the weaknesses of the operation personnel can be the low degree of communication culture. The important cause of communication problem for people working in different companies, especially in verbal communication, can be the lack of common communication culture. Not to record the conversations between personnel of shareholders and personnel working in the ground handling companies is another weakness of the verbal communication when the aircraft gets service on land.

Another success factor can be to come together by all shareholders semi-annually by meetings in order to determine the problems in the current system and try to solve them cooperatively, for example, there is no real-time monitoring system shared by all shareholders in Ataturk Airport. For this reason, operation personnel need to transmit the information about the starting and finishing times of the job repeatedly both to their companies and to other related companies. Moreover, routinely used documents are developed by the companies independently. So, these documents cause many problems when they have to be used for different companies. This situation increases the workload of the workers and decreases the efficiency of the workers. Lots of operation data are recorded in different formats and converted to statistics in different ways by the shareholders. Moreover, companies use various OIS' and they are not integrated to each other. Therefore, there are difficulties in data sharing of various companies. Besides, companies develop the same OIS' independently. Actually, it is better to develop and use the same OIS for all the companies. The system used for information screens and announcements is not so sufficient that they cause the delays of the flights due to not reaching the passengers on time. This system can be developed to increase the interaction between the passengers and shareholders in Ataturk Airport. One good solution for the close interaction can be the usage of RFID systems in the boarding tickets.

For the future studies, standards of the verbal communication in the steps of operation process can be examined and developed. These standards can help the companies to communicate easily and correctly. Some regulations can be made about the recording of the transceiver communication between the shareholders. Many of these verbal communication is not recorded, so many conflicts can happen among the shareholders while they do their jobs. Current models about the airline operation monitoring system are examined and new models can be suggested for Ataturk Airport.

\section{References}

ATAG. (2013). The economic and social benefits of air transport. Retrieved from http://www.atag.org/our-activities/social-a-economic-benefits-of-aviation.html

Ateş, S. S., \& Kağnıcıoğlu, C. H. (2013). Airline service process at Ataturk Airport: An analysis of the current situation. International Journal of Business, Humanities and Technology, 3(6), 34-43

Castro, R., \& Lewis, T. (2011). Corporate aviation management. Carbondale: Southern Illinois University Press. 
Clarke, M. D., Lettovsk, L., \& Smith, B. C. (2000). Handbook of airline operations. In G. F. Butler, \& M. R. Keller (Eds.), The development of the airline operation control center (pp. 131-146). New York: Aviation Week.

Curcio, D., Longo, F., Mirabelli, G., \& Pappoff, E. (2007). Passengers' flow analysis and security issues in airport terminals using modeling and simulation. Proceedings from 21st European Conference on Modelling and Simulation.

Directorate General of Civil Aviation. (1996). SHY-22. Havaalanlarl Yer Hizmetleri Yönetmeliği. Retrieved from www.dhmi.gov.tr/getBinaryFile.aspx?Type $=2 \&$ dosyaID $=204$

Directorate General of Civil Aviation. (2008). Standart yer hizmetleri anlaşması (SYHA) (1st ed.). Ankara: Havaalanları Daire Başkanlığı.

Gatersleben, M. R., \& Weij, W. (1999). Analysis and simulation of passenger flows in an airport termina. Proceedings from the 31 st conference on Winter simulation: Simulation-A bridge to the future.

Jim, H. K., \& Chang, Z. Y. (1998). An airport passenger terminal simulator: A planning and design tool. Simulation Practice Theory, 6, 387-396.

Kazda, A., \& Caves, R. E. (2000). Airport design and operation. Amsterdam: Pergamon.

Khan, M. (2000). Business process reengineering of an air cargo handling process. International Journal of Production Economics, 63(1), 99-108.

Kohl, N., Larsen, A., Lasren, J., Ross, A., \& Tiourine S. (2004). Airline disruption management-perspective, experiences, and outlook (The Technical University of Denmark: EU-funded project DESCARTES).

Ma, W., Kleinschmidt, T., Fookes, C., \& Yarlagadda, P. K. (2011). Check-in processing; simulation of passengers with advanced traits. Proceedings from the 2011 Winter Simulation Conference, Phoenix, IEEE.

Miles, M. B., \& Huberman, A. M. (1994). Qualitative data analysis. Thousand Oaks: SAGE Publication Inc..

Norin, A. (2008). Airport logistics modeling and optimizing the turn-around process. (Ph.D. Thesis. Linköping Studies in Science and Technology Licentiate Thesis No. 1388).

Société Internationale de Télécommunications Aéronautiques. (2013). Products and solutions. Retrieved from http://www.sita.aero/products-solutions? 